MYKOL ROMERIO
UNIVERITEIAS

\title{
DARA SHUKOH, ABUL KALAM AZAD AND ECLECTIC TRADITIONS IN INDIA
}

\author{
Amit Dey \\ University of Calcutta, Department of History \\ 3 Ajanta Park, Kolkata 700086, India \\ Telephone: (00 91 33) 24254645 \\ E-mail: profamitdey@gmail.com \\ Received 20 July, 2013; accepted 27 July 2013 \\ doi:10.13165/SMS-13-5-3-03
}

\begin{abstract}
In the contemporary world, multiculturalism and secularism are facing a serious threat from resurgent religious fundamentalism. Mughal Prince Dara Shukoh was the symbol of cultural pluralism. However, it is useful to remember that many saints and thinkers in India, before and after this liberal and eclectic prince, made sincere efforts to promote mutual understanding between different communities which in its turn created an environment of mutual appreciation. Meaningful dialogue between different communities is the sine qua non for human progress. The present paper aims at understanding the ideas and works of Dara Shukoh in this broader context.

Academics in India are mainly interested in Azad since he became a public figure. But the present paper aims at exploring the period of his blossoming in its proper historical setting. His future ideas and actions could be properly understood through this exercise. We have tried to study Dara and Azad in the light of South Asia's eclectic traditions.
\end{abstract}

Keywords: multiculturalism, mutual appreciation, resurgent religious fundamentalism, Dara Shukoh, Azad, South Asia's eclectic traditions. 


\section{Introduction}

In the contemporary world, multiculturalism and secularism are facing a serious threat from resurgent religious fundamentalism. Systematic efforts to homogenize human behavior and thinking are superficial acts which are capable of destroying the importance of cultural pluralism. There should be respect for different views and cultures. Mughal Prince Dara Shukoh was the symbol of cultural pluralism. However, it is useful to remember that many saints and thinkers in India, before and after this liberal and eclectic prince, made sincere efforts to promote mutual understanding between different communities which in its turn created an environment of mutual appreciation. Peaceful and meaningful coexistence based on creative interaction is not possible without such an environment. Thinkers are increasingly realizing the importance of meaningful dialogue between different communities which is the sine qua non for human progress. The present paper aims at understanding the ideas and works of Dara Shukoh in this broader context.

Academics in India are mainly interested in Azad since he became a public figure. But the present paper aims at exploring the period of his blossoming in its proper historical setting because we strongly believe that his future ideas and actions could be properly understood through this exercise which concentrates on his pre-public image. No in-depth study of Azad is possible without this approach. Often a multi-disciplinary approach is useful in this respect. We shall try to study Dara and Azad in the light of South Asia's eclectic traditions.

\section{Review of Periodization of History}

Those who talk about the Indian Renaissance generally speak about the 19th century Renaissance which according to the reviewers was the outcome of India's exposure to Western civilization and culture. No one can deny that India's interaction with the west was extremely significant. But the reluctance to trace the history of enlightenment in India before the advent of colonial rule is very unfortunate ${ }^{1} .{ }^{1}$ For a proper understanding of the history of enlightenment in India it is useful to study the events during the Sultanate and Mughal period or even earlier. It is not surprising that Abul Kalam Azad was a keen observer of the developments in Mughal India, particularly during the 16th century. This is a defining century in the socio-religious history of the subcontinent because of Akbar's experiments, advent of the Naqhsbandi Sufis and the Europeans in India, and last but not the least, the increase in the number of Hajis (those who have performed the Haj pilgrimage) confirming the linkages between the Mughal Empire and the Hijaz (Arab World). Modernizing trends could be visible in the so called medieval period whereas backwardness is noticeable in the so

1 De, A. Madhyayuger Prekshapate Bharatiya Renaissance, in Bratindranath Mukherjee ed. India And Indology: Professor Sukumari Bhattacharji Felicitation Volume. Kolkata, National Book Trust, 2009. 
called colonial/post-colonial period. Intermingling and a mixture of different traditions characterized Indian civilization even before Kabir and Dara Shukoh. For example, Kabir was influenced by both the astika (theistic) and nastika (atheistic) traditions. Whereas his philosophy and faith were soaked in the astika spirit, the vitality and freedom of his individual reasoning was a clear manifestation of the nastika tradition ${ }^{2}$. While the rationalist Mutazilities were persecuted in West Asia, popular devotion and rationalism found acceptance in the 11 th and 12 th centuries India.It is not surprising that India emerged as a favourite destination for Sufis from Central and West Asia.

\section{Linguistic Intermingling and Vernacularization}

The appropriating nature of Sufism made Islam a world religion. Instead of promoting the process of Persianization, the leading sufi saints in India often encouraged vernacularization of religious knowledge in order to reach out to the common people. This did not mean that they discarded Persian, but alongside that classical language, local languages such as Hindawi or Punjabi also got importance. Amir Khusrau's experimentation with Persian and Brajabhasha is well known. Like the Sufis the Bhakti saints also encouraged this vernacularization process ${ }^{3}$. This linguistic intermingling which we can call "Majma-ul-Zabanat" actually preceded Dara's "Majma-ulBahrain" or intermingling of two oceans, Hinduism and Islam. In this way a liberal and healthy environment was created in many parts of India even before the advent of Dara. Acceptance of local languages has shown that the Sufis were prepared to respect indigenous culture. Recognition of diversity is essential for meaningful and peaceful coexistence. It is useful to note in this context that Azad's mothertongue in the literal sense of the term was Arabic. He also mastered another classical language, Persian. He was not very fluent in English but was proficient in local languages such as Urdu and Hindi.

\section{Spirit of Mutual Understanding}

Scholars such as Satish Chandra, Amalendu De and others have pointed out that the spirit of mutual understanding and mutual appreciation was strengthened by the interaction between the bhakti and sufi movements in the Indian subcontinent and this process started earlier than the age of Dara. This spirit of interaction was also reflected in Indian literature, arts and music. Great scholar Al Biruni, a forerunner of Dara, translated Patanjali's Yoga Sutra into Arabic. Yogis used to visit sufi hospice

2 Sharma, K. Bhakti and the Bhakti Movement; A New Perspective, 2nd ed. New Delhi, Munshiram Manoharlal Pub. Pvt. Ltd. 2002, p. 178.

3 De, A. Presidential Address, 220 $0^{\text {th }}$ Annual General Meeting of the Asiatic Society, 2003 - 04, Kolkata. Title: "Theological Discourses in Indian History". Also see Chandra,S. Historiography, Religion and State in Medieval India. New Delhi, Har-Anand Publication, $2^{\text {nd }}$ rpt. 2001, chapters 8 and 9. 
(khanqah) and Jamat Khanah's run by the Sufis ${ }^{4}$. So there was a scope for interaction. It is a well known fact that some of the Sufis including the illustrious Shaikh Nizamuddin Auliya adopted some breathing exercises. This was apparently the influence of the Yogis. In this context it would be appropriate to discuss the Sufi doctrine of Wahdat $-u l-w a j u d$ or pantheism. The Sufis use a term 'Hama Ust' meaning everything is 'He'. Which implies that God is reflected in everything. Using this doctrine some Sufis went to the extent of claiming that God is also reflected in a heathen or a Hindu and under such circumstances a Hindu cannot be denounced as a kafir or 'infidel' ${ }^{5}$. Mulla Daud, the author of Chandayan, was linked to the famous 14th century Sufi Nasiruddin Chiragh-i-Delhi, Praised Muhammad as 'the beloved of everyone'. At the same time he referred to the Vedas and Puranas as revealed books, like the Quran ${ }^{6}$. Mirza Mazhar Jan- $\mathrm{i}-$ Janan, a naqshbandi (a sufi order) sufi poet came to the same conclusion as Dara, viz. that the Vedas were revealed books, and hence Hindus could not be identified with the Kafirs of Arabia. He even argued that there was little difference between idol worship and tasawwar-i-shaikh (common among those - who venerate a sufi saint) or concentration on the mental image of the preceptor ${ }^{7}$. Interestingly, in spite of sharing their views with Dara, these people were not persecuted. At the same time one has to remember that they were not Dara's contemporaries. What would have been their fate if they had flourished during the same period is a different question.

The translation of various Sanskrit works into Persian was undertaken by Sultan Zaynul Abidin of Kashmir, Sultan Sikandar Lodi and several other Muslim rulers not only "to satisfy their own intellectual curiosity" but also "to increase Muslim understanding of Hinduism". This process acquired a new direction under Akbar. The Ramayana and Mahabharata were translated into Persian in the Maktab Khana set up by Akbar. The preface to the Mahabharata was written by Abul Fazl who "urged his Muslim readers to study his account of Hindu learning with open minds". The theological debates transformed Akbar's spiritual life. He came into contact with other religions and was convinced that "all religions contained some truth and that this was not the prerogative of Islam. "He also "believed that constant self-examination was a spiritual exercise of prime importance and that no action should be taken without sound reason". In this way Akbar "sought to heal the religious differences among his subjects".

Like his great forefather Akbar, Shah Jahan's favourite elder son Prince Dara probably realized the fact that religious exclusivity of the ulama would not be helpful to run a vast multicultural empire like India, and deliberately tried to strengthen some

4 De, A. supra note 3

5 Hughes, T.P. Dictionary of Islam.New Delhi, Munshiram Manoharlal Pub, Pvt. Ltd., New Edition, 1999, see Wahdat - ul - Wajud. Also, Chandra,S. Historiography, Religion and State in Medieval India. New Delhi, Har-Anand Publication, $2^{\text {nd }}$ rpt. 2001

6 Chandra,S. Historiography, Religion and State in Medieval India. New Delhi, Har-Anand Publication, 2nd rpt. 2001,p.139.

7 Chandra,S. supra note 6, p.151.

8 De, A. supra note 3, p.10 
institutions such as Sufism, which celebrated the composite nature of Indian culture. If we accept this hypothesis, it would imply that there was a political agenda behind the eclecticism of Akbar and Dara. Whatever may be the prime reason, there is no denying the fact that their ideas and activities nourished the inclusive and composite nature of Indian society and polity. Indeed, present day statesmen have much to learn from them.

\section{Dara Shukoh, a Renaissance Personality}

Dara was a sound scholar, poet and calligrapher with an artistic bent of mind. But unlike his great forefather Akbar, he was not adept in the art of statecraft. It is said that Emperor Shah Jahan advised his eldest son Dara to acquire the knowledge available in the Greek, Roman and Persian worlds alongside the knowledge prevalent in India. After completing this process, Dara should, according to his father, launch his career like a second Alexander (Sikander Sani). However, it was not Dara's desire to be another conqueror, he rather wanted to be a thinker ${ }^{9}$. It appears from his famous work Majma -ul-Bahrain that he believed in Ijtihad, or right of the learned to interpret scriptures according to changing circumstances. In other words, he put emphasis on Aql or reason, like his predecessor Akbar and cultural successor Raja Rammohun Roy. Actually, the clash is not between different civilizations, the clash is within Islam, it is between Ilm (here the term Iim or knowledge has been used in a narrow sense, meaning scriptural knowledge) and Aql (Reason). The door of Ijtihad being partly closed, Aql appears to have taken a back seat within Islam. But, till the 10th century, when the Mutazila (rationalist school) was still around, the term Ilm was used in the broad sense as it allowed Aql (Reason) to be its integral part. Through different phases, spanning over several centuries, Islam experienced the reassertion of orthodoxy, which reduced the term ilm, virtually to the status of literal fundamentalism or scripturalism. Eminent historian, Muzaffar Alam has implied in his scholarly work, that with the advent of western political dominance since the late 18th century, the nervousness of the ulama increased, and they renounced and denounced the spirit of experimentation which actually made Islam a world religion. In this way, the door of ijtihad was partly closed during the colonial milieu, culminating in the decline of $A q l$ (Reason) in Islamic societies $^{10}$. Majority of the Muslim theologians still believe, that if experimentation is allowed to continue, Islam could be overwhelmed by the "other". This situation is posing a serious threat to India's eclectic traditions.

Dara was only twenty five when he produced his very first work in Persian entitled Safinat-ul-Awliya (The Notebook of The Saints). He mentions in the introduction to this work that he used to venerate the Sufis and the religious divines, and had studied their lives closely but was disappointed to find that the details of their lives were scattered in the pages of so many different manuscripts, so he decided to produce this work in order

9 De, A.; Nabachetanar Dui Agrapathik; Dara Shukoh Rammohun Roy, in Dilip Kumar Biswas, Pratul Chandra Gupta and others; Rammohun Swaran, (in Bengali) p. 294.

10 Alam, M. The Languages of Political Islam in India. New Delhi, Permanent Black, 2004. 
to provide, within a very small canvas, the details regarding the dates of birth and death, the place of burial and other important particulars of the saints of Islam ${ }^{11}$. Without being sectarian, Dara in this book wrote about various sufi orders. However, the most significant part of this work is the author's focus on women as he deals with the wives and daughters of the Prophet and some female mystics. Some scholars on gender issues often imply that the gender discourse is the direct outcome of India's exposure to the West. I suggest with all humility, that they can provide a new dimension to their gender related research if they can spare some time and energy to understand the Indianness of this discourse as prevalent in pre- colonial India. Consulting Indian sufi literature available in Persian it can be proved that this legacy pre-existed Dara. For example the great Chishti saint Nizamuddin Awliya (d-1325) said; "If a lioness emerges from the forest, no one raises any question about its sex ." Actually a lioness is equally dangerous from the point of view of a human being. The implication is that a learned woman can acquire same spiritual status like her male counterpart. A shariat - centred or scripture oriented pious scholar, Abdul Haq Dehlawi, a contemporary of Jahangir, devoted an entire chapter in his famous work Akhbar-ul-Akhyar to female mystics ${ }^{12}$. Inclusion of such an issue in the work of a theologian indicated that unlike many of their modern counterparts, they reflected a liberal attitude to the gentler sex. Bikrama Jit Hasrat ${ }^{13}$ has shown that Dara was not only respectful to female mystics, he was also in favour of his talented sister Jahanara acquiring spiritual knowledge ${ }^{14}$.

In Majma - ul - Bahrain, there is clear evidence to prove that Dara acquired knowledge about Tauhid (monotheism) and Irfan (Divine knowledge). The latter is a Quranic word. The selection of such a word by Dara is significant but not surprising Dara did not renounce Islam officially. However, his rivals tried to denounce him as an infidel, which served their narrow political interest. I share my views with American scholar Professor Brian Hatcher, noted for his research on the Brahmas, pundits and Vidyasagar, that many Hindus in colonial Bengal such as Raja Rammohun Roy and Raja Radhakanta Dev, were well versed in Persian. In order to study India's composite culture, it is equally important to carry out research on Muslims in colonial and pre - colonial India who were well versed in Sanskrit. One ideal example in this line is indeed Dara Shikoh. His Sanskrit learning enabled him to explore and appreciate Upanishadic monotheism, which according to him was not different from Quranic monotheism. From 1065 AH onwards, he was more deeply interested in the study of Hinduism. In 1066 A H he got the Jug Bashist translated into Persian. Shortly, after, he himself translated the Upanishads into Persian prose. Most probably, he had Bhagvat Gita translated by one of his courtiers ${ }^{15}$.

11 Majma - ul - Bahrain, by Dara Shukoh, edited in the original Persian with English Translation, Notes and Variants by M. Mahfuz - ul - Haq. Kolkata, The Asiatic Society, first published 1929, rpt. in 1982. p.5.

12 See my book Dey, A. Sufism in India, Calcutta, Ratna Prakashan, 1996.

13 Bikrama Jit Hasrat Dara Shikoh: Life and Works. Bikrama Jit Hasrat Dara Shikoh: Life and Works.New Delhi: Munshiram Manoharlal Publishers Pvt. Ltd., 1979, rpt. 1982.

14 Bikrama Jit Hasrat, supra note 13.Also Dey, A., supra note 12.

15 Majma - ul-Bahrain, supra note 11, p.28. 
In his Hasanat-ul-Arifin, which he completed in 1064 A. H., Dara included the name of Baba Lal- the only Hindu whose aphorisms he has quoted. In the Majma-ulBahrain also ${ }^{16}$, Dara put down the name of this saint, whom he calls Baba Lal Bairagi, by the side of those Muslim saints and divines who have been the best representatives of Islamic mysticism. The inclusion of the name of a Hindu is such an exclusive list of Muslim divines shows unmistakably the high esteem in which this devotee was held by Dara ${ }^{17}$ Dara invited the saint and had conversations. It appears that Dara's private secretary, Chandar Bhan, was present on the occasion of these interviews and perhaps, acting as an interpreter ${ }^{18}$. It is useful to note that Dara's eclectic mind was so broad that he did not confine his efforts to explore the commonalities between Hinduism and Islam only. He was also thinking about including other religions in his project such as Christianity. Apparently this inclination of Dara was manifested in the year 1640-41, when he carefully studied the Bible ${ }^{19}$.

It will be appropriate to wind up the discussion with a few examples from the Majma. This book begins with an interesting verse; "Faith and Infidelity, both are galloping on the way towards Him." Apparently Abul Fazl had this verse inscribed on a building which Akbar had built for the common use of the Hindus and the Muslims ${ }^{20}$. It was a clear manifestation of the fact that Dara derived inspiration from the eclectic spirit which was sustained and enhanced by the policy undertaken by his great grandfather. In the pages of Majma ${ }^{21}$, Dara portrayed himself as a faqir endowed with esoteric knowledge (llm-I-Batin) with which he aspired to know the tenets of religion of the Indian monotheists. Dara was elated to find that the difference between Indian monotheism and Islamic monotheism was only verbal.

\section{Legacy of eclecticism during the $19^{\text {th }}$ and $20^{\text {th }}$ centuries}

Dara Shukoh's Persian version of Upanishads entitled Sirr-i-Akbar was translated into Latin in 1800. At a later period Arthur Schopenhauer, the famous German philosopher, was influenced by this work. Dara Shukoh should rightly be called a propounder of the concept of modernism based on universalism, which was more visible in the ideas and activities of Rammohun Roy since the beginning of the $19^{\text {th }}$ century. Roy, in his various works such as Manazaratul Adian (in Arabic, no longer available), Tuhfat-ul-Muwahhidin (in Persian), Vedanta Sara (1815) and other works on Upanishad, expressed his ideas on theological issues. He had analyzed theological issues from the liberal - human - rational viewpoint. Like Dara, Roy's religious ideas

\footnotetext{
16 Majma-ul-Bahrain, supra note 11, p. 24.

17 Ibid.

18 Ibid.

19 De, A. supra note 9

20 Majma-ul-Bahrain, supra note 11, p. 37.

21 Ibid, p. 38.
} 
were also helpful to the growth of a new consciousness in a multi - religious country like India ${ }^{22}$.

By, bringing the people of different faiths closer to each other, the charismatic Brahmo leader Keshab Chandra Sen (1838-1884) wanted to build up a new human society. With this aim in view, he instructed some of his closest disciples to study Hinduism, Buddhism, Christianity and Islam. Bhai Girish Chandra Sen studied Islam and for that learnt Arabic, Persian and Urdu. Besides the Quran, he translated several books on Islam from Arabic, Persian and Urdu into Bengali ${ }^{23}$. Picking up the eclectic thread from Dara Shukoh, nationalist leader and theologian Maulana Abul Kalam Azad (1888-1958) interpreted Islam from a different perspective. His own outlook was marked by a universal Islamic humanism very much in tune with the liberal sufi traditions. He tried to build Indian society on the basis of her cultural pluralism ${ }^{24}$.

In an era, when the forces of religions extremism is moving from strength to strength, it has become increasingly important to reassess the role of the personalities like Dura Shukoh, Rammohun and Azad in the context of 'multiculturalism', if we may use the term.

Academics in India are mainly interested in Azad since he became a public figure. But the present paper aims at exploring the period of his blossoming in its proper historical setting because we strongly believe that his future ideas and actions could be properly understood through this exercise which concentrates on his pre-public image. No in-depth study of Azad is possible without this approach. Often a multi-disciplinary approach is useful in this respect and not surprisingly one of the best works on Azad actually emerged from the pen of a theologian and not historian. The remarkable scholar who wrote that timeless thesis on Azad is Ian Henderson Douglas, who did not live to see its publication. That job of editing was left to two leading scholars on Islam such as Gail Minault and Christian W. Troll.

Since Azad's ideas or actions did not subscribe to the two national theories, the direct or indirect beneficiaries of such separatist ideology in South Asia seldom talk about him. Jinnah, the father of the only state in human history which was formed on the basis of religious identity, was not known to be an ideal Muslim in his private life, and who did not spend a single day in colonial prison, was extrovert, persuasive and assertive. Whereas Azad's political career is characterized by several phases of incarcerations in the colonial era. Volumes of literature on Jinnah is available though unlike Azad, Nehru or Gandhi, he did not take the pain to write down anything for the posterity. Volumes dedicated to the lives of Gandhi and Nehru are also swelling. But Azad, who did not inherit the crowd pulling potentiality of his sufi father was not always comfortable with the masses. Introvert and scholarly Azad's comfort zone was apparently the quietude of a kutb khana or library. Not a persuasive speaker unlike Jinnah, Nehru or Gandhi, Azad still demands the attention of serious historical research.

22 De, A. supra note 3, p. 11-12.

23 De, A. supra note 3. and Dey, A. The Image of the Prophet in Bengali Muslim Piety; 1850 - 1947. Kolkata, Readers Service. 2005, chapter 3.

24 De, A. supra note 3. 
Colonial period in South Asia witnessed the reduction of historical research into three rigid periods, such as ancient, medieval and modern. In his keynote address, delivered in Calcutta university on 06 March, 2012, eminent historian Harbans Mukhia anticipated the importance of historical research which will concentrate on historical processes rather than mechanical periods, and when historians will feel it reasonable and comfortable to select a broader canvass, often necessary to provide a more comprehensive analysis of historical events, evolution of ideas or moulding of personalities.

Being inspired by such tendencies in the realm of intellectual discourse we would like to explore whether developments in the 16th century India can help us to study a 12th century personality such as Azad.

The 16th century can be regarded as a defining century so far as South Asian Islam is concerned. During this century India experienced the advent of the Europeans and the Naqshbandi Sufis. As compared to other sufi silsilahs or orders, the Naqshbandis were known to be orthodox and more inclined towards scriptural Islam. They expected the Muslim rulers in India to govern in strict conformity with the sharia or canon law of Islam. Interestingly other major sufi silsilahs such as the Chistis, Qadiris or Suhrawardis traced their genealogy from Ali (son in law of the Prophet) and Fatima (beloved daughter of the Prophet and wife of Ali) who represent mystical Islam. Whereas the Naqshbandis trace their origin from Abu Bakr, the first caliph who represented scriptural Islam. The cases of Hajj pilgrimage also increased during the 16th century when Akbar the great Mughal could establish Pax Mughalica or Mughal Peace. The ritual dynamism associated with Hajj and access to the Hijaz or Arab world significantly enhanced interests in the Quran and the hadith, which are regarded as the universal symbols of Islam. In this way a conducive environment was created for the development of a Quran and hadith centred piety in medieval India. Actually, even before the advent of the Mughals. Delhi started to emerge as a leading centre of Islamic learning. This was possible largely due to the Mongol inroads in West Asia which contributed to the influx of Sufis, ulama, artists, poets and mercenaries from that region to the Indian subcontinent. Delhi had multiple identities even during the Sultanate period such as political identity being the citadel of power, spiritual identity because of the prevalence of Sufis such as Kaki or Nizamuddin Awliya, cultural centre because of Amir Khusrau, the land of scholars because of the court historians such as Zia Barani and a section of the ulama devoted to the study of scriptures. A few centuries later, during the age of the great Mughals, the ancestors of Abul Kalam Azad would be nourished in that Delhi tradition. Azad, just like any other ashraf or well born Muslim who claimed foreign origin, was very proud of his ancestry. But unlike a section of the separatist ashraf of the 20th century India, he emerged as an eclectic and inclusive ashraf, who could not accept the vivisection of India on the ground of religion.

When we say that Azad was proud of his ancestry we are aware that he had an ambivalent relationship with his father implying that regarding various issues he had strong disagreement with his father. Still he was respectful towards his father and appreciated the reading habit in his family which was not common in the family of pirs 
where a boy child was assured of enhanced social status from the time of his birth. In spite of difference in opinion Azad never failed to appreciate his father's fascination for books which accompanied him in several boxes when he used to travel from one place to another. Azad's mother was an Arab who always spoke in Arabic with his father. Azad regarded Arabic as his mother tongue and observed with delight how his mother and female relatives from her side could fluently interact with women of the neighbourhood during their stay in the middle east and addressed some of the problems they faced. Azad's father expected the female members of his family to acquire knowledge, and would not object to the entry of a Shia teacher in the family if that person was capable of imparting knowledge to young Azad. This craze for acquiring knowledge was unique among the pirzadas (sons of pirs) of South Asia. So Azad felt blessed by that environment in the family in spite of all the personal crisis he had to encounter during adolescence. Azad admitted his intoxication with Sir Sayyid Ahmad's works. His avid reading of translated western books confirms the fact that he was open minded and inquisitive, a quality not very common among a section of the orthodox ulama. At one point, Azad went beyond the rationalism of Sir Sayyid and became inclined towards 'unbelief'. Considering the religious environment of his family, this was unique, and here he resembled any western counterpart charged with the spirit of enquiry during the 'Age of Reason'. The receptive and dynamic mind of young Azad was not only curious about Arab Nationalism, which became a significant phenomenon during his preparatory stage but he also became a keen observer of the Swadeshi Movement which engulfed Bengal in the aftermath of the 'infamous'(not infamous among the separatist Muslims) Bengal Partition. Azad's family was the confluence of three learned families of Hijaz (Arab World) and Hindustan. Though Azad regarded Arabic as his mother tongue which also enabled him to access literature dealing with Arab Nationalism, interestingly he was more proud of his paternal (Indian) ancestry than his maternal (Arab) ancestry. In this sense his concept of 'location" ${ }^{25}$ was also unique among the ashraf (High born Indian Muslims who claim foreign origin) Muslims. A large section of the ashraf Muslims associate their concept of 'location' with extra territoriality (beyond India) which can be traced in West Asia or the Arab world. I draw your attention to this Indianness of Azad which was anticipated earlier by poet Amir Khusrau, Akbar the Great or the tragic hero Dara Shukoh. So, it can be deduced that heterogeneity characterizes ashraf Muslims with 'locations'. The self-styled champions of literal fundamentalism, particularly the separatists or the protagonists of 'Two Nation' theory tend to deny this heterogeneity to the ashraf. They played a remarkable role in minimizing the images of eclectic personalities such as Akbar, Dara or Azad. Their relative success is confirmed by the fact that Azad is one amongst the least researched or discussed nationalist leaders in South Asian history. Even in the 1970s, Dara Shukoh's birthday used to be symbolically celebrated in Kolkata both by progressive Hindus and Muslims. Veteran Bengali journalist Abdur Rauf (associated

25 Hindustani location, I have borrowed the term from Neshat Quaiser's article Medicine and Public Sphere in Colonial India, Summerhill, IIAS, Rashtrapati Nivas, Shimla 171005, ISSN: 0972-1452, 1998, December. 
with Bengali journal Chaturanga ) was one of those enthusiasts. Long time ago, Tagore, while speaking or writing on Hindu Muslim relations, realized the importance of Dara in Indian history. Do or should the young generation in the $21^{\text {st }}$ century subcontinent bother about Dara or Azad in the age of information revolution?

The steadfastness of Azad would be properly understood if we study his admiration for some of his upright and brave ancestors. They did whatever they believed should be done, irrespective of the consequences. Shaikh Jamaluddin, one of theologian Azad's ancestors who was also credited with making India famous for hadith instruction, opposed Emperor Akbar's claim to be an imam. He also courageously supported the Naqshbandi theologian Shaikh Ahmad Sirhindi when he lost favour at Jahangir's court $^{26}$.

One of Azad's ancestor's came from Hirat with Ahmad Shah Abdali but lost his life while fighting the Sikhs. Azad cherished the heroics of such independent minded ancestors. Ironically, his son Munawwaruddin eventually became the Mughal Director of Education as if anticipating the Education Minister(Azad himself) of postcolonial India. Indians with Wahhabi leanings were persecuted in Hijaz. The rejection of taqlid (to accept without question the authority of early Muslim jurists in matters of Muslim law; to follow authority without reflection) by the Waliullahis antagonized Azad's father Khairuddin towards them. Unlike his father Azad was in favour of ijtihad (independent thinking, according to eminent sociologist Asoke Basu). Charismatic preacher Khairuddin could attract a crowd of 30000 on Calcutta Maidan. While emotion was central to his intellectual and practical interests, his son Azad's emotions were those of the poet or the artist. They were controlled. This aristocratic calmness was shared by a large number of ashraf. Khairuddin was unprejudiced so far as different religions were concerned but he could not hide his anti Wahhabi feelings. Azad had an ambivalent and complex relationship with his father Khairuddin. On the one hand Azad did not share his father's attitude towards taqlid and pir-muridi. Azad felt embarrassed at a tender age when he found that his father's (who was a pir) elderly disciples (murids) were venerating him as the pir zada (son of a pir). In fact the lord-vassal relationship as manifested in the pir-muridi and the irrational approach that characterized taqlid epitomize a feudal society, which Azad apparently discarded probably because of his exposure to western literature or knowledge through translations. This is the least discussed aspect of Azad's eclectic character. On the other hand he appreciated his father's reading habit as he mentions with pride how his father would travel from place to place with boxes filled with books. His father spent one or two years in Constantinople and Cairo simply for books. Apparently at the subconscious level, Azad also inherited his father's tolerant attitude towards different religions. A devout Muslim, Azad was a dignified man who would not emulate those Khilafat leaders who showed exaggerated respect to Gandhi.

26 Arthur Buehler's monumental work on Sirhindi is recently published. According to Dr Buehler, Sirhindi is regarded as a hero by a section of the Pakistani population whereas he is denounced in India for his alleged exclusivism. 
Often it is observed that eclectic personalities are multilingual such as Ameer Khusrau, Dara Shukoh, Raja Rammohun Roy, Bhai Girish Chandra Sen, Gandhi or Rabindranath Tagore. Azad was no exception. He was bilingual at home. Arabic was his mother tongue in the literal sense. He spoke Urdu with his father and his disciples. He also knew Persian and English and could follow Bengali. While delivering lectures or writing articles on the promotion of Hindu-Muslim amity, Tagore had pointed out that the politicians shout about communal harmony but such gestures lack substance. Knowing the neighbourhood is very important for promoting Hindu-Muslim understanding based on mutual appreciation. In this context, Tagore spoke highly about the medieval mystical saints of Islam. Azad was probably that ideal man Tagore was speaking about, who would understand religion in the true sense of the term. Therefore, he would try hard to discover the essence of religion, and would realize that a truly devoted man cannot cherish hatred against the neighbours. This also reminds us of Gandhi, who unlike other politicians, spent three valuable years only to learn Urdu so that he could access Islamic scriptures necessary to know the Muslim neighbourhood in his heroic struggle against the cynical 'Two Nation' theory eventually contributing to the vivisection of India ${ }^{27}$.

\section{References}

Alam, M. The Languages of Political Islam in India. New Delhi, Permanent Black, 2004.

Bikrama Jit Hasrat Dara Shikoh: Life and Works.New Delhi: Munshiram Manoharlal Publishers Pvt. Ltd., 1979, rpt. 1982.

Buehler, A. F. Revealed Grace: The Juristic Sufism of Ahmad Sirhindi (1564-1624). Fons Vitae, 2012

Chandra, S. Historiography, Religion and State in Medieval India. New Delhi, Har-Anand Publication, $2^{\text {nd }}$ rpt. 2001.

De, A. Bharater Muslim Rajnitir Gati Prakriti. Kolkata, Raktakarabi, 2009.

De, A. Madhyayuger Prekshapate Bharatiya Renaissance, in Bratindranath Mukherjee ed. India And Indology: Professor Sukumari Bhattacharji Felicitation Volume. Kolkata, National Book Trust, 2009.

De, A. Presidential Address, 220 $0^{\text {th }}$ Annual General Meeting of the Asiatic Society, 2003-04, Kolkata. Title: "Theological Discourses in Indian History".

De, A.; Nabachetanar Dui Agrapathik; Dara Shukoh Rammohun Roy, in Dilip Kr. Biswas, Gupta, P. Ch. and others; Rammohun Swaran, (in Bengali) p. 294.

Dey, A. Sufism in India, Calcutta, Ratna Prakashan. 1996.

Dey, A. The Image of the Prophet in Bengali Muslim Piety; 1850-1947. Kolkata, Readers Service. 2005.

27 To write the portion on Azad I have relied and intellectually responded to some scholarly works such as, Abul Kalam Azad: An Intellectual and Religious Biography by Ian Henderson Douglas, ed. by Gail Minault and Christian W.Troll. I have also consulted Tagore's articles and published speeches on Hindu-Muslim Relations (In Bengali Swadesh Samakal Granthamala-3, Hindu Musalman Samparka, Rabindra Rachanar Sangraha by Nityapriya Ghosh, pub. Mrittika.). I have studied Amalendu De's Bharater Muslim Rajnitir Gati Prakriti. pub. Raktakarabi, Kolkata). Last but not the least my interactions with Prof. S Irfan Habib, Maulana Azad Chair, NUEPA, New Delhi, have been extremely fruitful. 
Douglas, I.H. Abul Kalam Azad, an Intellectual and Religious Biography. eds.Gail Minault, Christian W. Troll. Oxford University Press. 1988.

Hughes, T.P. Dictionary of Islam.New Delhi, Munshiram Manoharlal Pub, Pvt. Ltd., New Edition, 1999, see Wahdat - ul-Wajud.

Majma - ul - Bahrain, by Dara Shukoh, edited in the original Persian with English Translation, Notes and Variants by $\mathrm{M}$. Mahfuz - ul - Haq. Kolkata, The Asiatic
Society, first published 1929, rpt. in 1982. p.5.

Quaiser, N. Medicine and Public Sphere in Colonial India, Summerhill, IIAS, Rashtrapati Nivas, Shimla 171005,ISSN: 0972-1452, 1998, December.

Sharma, K. Bhakti and the Bhakti Movement; A New Perspective, $2^{\text {nd }}$ ed. New Delhi, Munshiram Manoharlal Pub. Pvt. Ltd. 2002, p. 178.

\title{
DARA SHUKOH, ABUL KALAM AZAD IR EKLEKTIŠKOSIOS TRADICIJOS INDIJOJE
}

\author{
Amit Dey
}

Kalkutos universitetas, Indija

Santrauka. Šiuolaikiniame pasaulyje kaip rimta multikultūriškumo ir sekuliarizmo grèsme iškyla religinio fundamentalizmo įsigalejjimas. Mogolu princas Dara Shukoh buvo pliuralistinès kultūros simbolis. Tašiau verta prisiminti, jog daug šventuju ir mastytojų, Indijoje gyvenusin ir iki, ir po šio liberalaus ir eklektiškai nusiteikusio princo, kilniaširdiškai darbavosi skleisdami savitarpio supartimo dvasia tarp atskiru bendruomeniu ir taip radosi abipuses tolerancijos aplinka. Prasmingas įvairiu bendruomeniu dialogas žmonijos pažangai jau tapo sine qua non. Šiame straispnyje žvelgiama i Daros Shukoh idejjas ir darbus šiame plačiame kontekste.

Azad kaip viešas asmuo pritraukia dangiausia akademinès visuomenès dèmesio. Tačiau šiame straipsnyje siekiama apžvelgti jo klestejimo laikotarpi atsižvelgus i istorine aplinka. Tokiu büdu galima tinkamai ivertinti jo tolesnes mintis ir veiksmus. Mes tyreme Daro ir Azado veikla Pietu Azijos eklektiškosios tradicijos aspektu.

Reikšminiai žodžiai: multikultūriškumas, savitarpio pakantumas, stiprejjantis religinis fundamentalizmas, Dara Shukoh, Azad, Pietu Azijos eklektiškoji tradicija.

Amit Dey, Indijos Kalkutos universiteto Istorijos katedros profesorius. Mokslinių tyrimų kryptys: Indijos viduramžių istorija, islamo idejos.

Amit Dey, Calcutta University, Department of History, Professor. Research interests: Medieval Indian History, Islamic Thought. 